\title{
Analisis Optimasi Input Produksi Jagung di Desa Waimangurah, Kecamatan Wewewa Barat, Kabupaten Sumba Barat Daya
}

\author{
JENETE PRISKILA MANGNGI, I DEWA GEDE AGUNG, \\ NI WAYAN PUTU ARTINI
}

\author{
Program Studi Agribisnis, Fakultas Pertanian, Universitas Udayana \\ J1. PB. Sudirman Denpasar 80233 \\ Email: jenhypriskila_mangngi@yahoo.com \\ dewagedeagung@unud.ac.id
}

\begin{abstract}
Analysis on Input Optimization of Corn Production in Waimangura Village, Sub-District ofWest Wewewa, Southwest Sumba Regency
\end{abstract}

The purposes of the study were: to determine the influence of factors of production in corn farming on production and to analyze the level optimum use of production inputs in the corn farming. The research area was determined purposively. The analytical methods used to analyze the production inputs that affect the production were a Cobb-Douglass model of Production Function, and marginal product value analysis to determine the level of optimization of the use of production inputs. The results of the study are as follows: (1) Production inputs used in the corn farming are the area of land, seed, labor, Urea, NPK fertilizer, M-8 fertilizer, Super ACI fertilizer and fungicides. (2) The use of production inputs in the study area are as follows, Partially, only urea fertilizer significantly affected the corn production, while other production inputs were not significantly affected on the corn farming. (3) The use of production inputs in the study area have not been optimal. For the use of production inputs of urea, M-8 and Super ACI fertilizers was not optimal. Thus, the use of production inputs need to be added to reach optimal use of production inputs, while land, labor, seed, NPK fertilizer and fungicides have exceeded the optimal use so that the use of inputs should be reduced to gain optimal results.

Keywords: corn farming, production inputs, optimization

\section{Pendahuluan}

\subsection{Latar Belakang}

Bagi Indonesia, jagung merupakan tanaman pangan kedua setelah padi. Bahkan di beberapa tempat, jagung merupakan bahan makanan pokok utama pengganti beras atau sebagai campuran beras. Kebutuhan jagung di Indonesia cukup besar yaitu lebih dari 10 juta ton pipilan kering per tahun (Khalik, 2010).Produksi jagung dunia menempati urutan ketiga setelah padi dan gandum yaitu sebesar 612,5 juta ton. Distribusi penanaman jagung terus meluas di berbagai negara di dunia 
karena tanaman ini mempunyai daya adaptasi yang luas di daerah subtropik ataupun tropik. Indonesia merupakan negara penghasil terbesar di kawasan Asia Tenggara, maka tidak berlebihan bila Indonesia mencanangkan swasembada jagung (Rukmana, 2008).

Jagung (Zea mays. L) sangat bermanfaat bagi kehidupan manusia ataupun hewan. Bagi Indonesia jagung merupakan makanan pokok kedua setelah padi. Berdasarkan urutan bahan makanan pokok di dunia, jagung menduduki urutan ketiga setelah gandum dan padi. Jagung merupakan salah satu tanaman pangan yang memiliki peranan strategis dan bernilai ekonomis serta mempunyai peluang untuk dikembangkan. Jagung sebagai sumber utama karbohidrat dan protein setelah beras, disamping itu jagung juga berperan sebagai bahan baku industri pangan, industri pakan, dan bahan bakar (Siregar, 2009).

Beberapa faktor penting yang perlu diperhatikan dalam upaya peningkatan produksi jagung diantaranya adalah penggunan input produksi yang optimum. Faktor-faktor tersebut saling berkaitan sehingga dalam peningkatanproduksi jagung diperlukan pemahaman untuk mengelolanya agar bersinergis sehingga diperoleh hasil yang tinggi(Suwardi dan Roy,2009).

Kecamatan Wewewa Barat, khususnya di Desa Waimangura merupakan daerah yang masyarakatnya kebanyakan megusahatanikan tanaman jagung. Berdasarkan data dari Badan Pusat Statistik Kabupaten Sumba Barat Daya, luas panen di Kecamatan Wewewa Barat mengalami sedikit penurunan dari 4.785hektar di tahun 2013 menjadi 4.296hektar di tahun 2014. Demikianpun halnya dengan jumlah produksi yang menurun dari 18.138 ton ditahun 2013 menjadi 16.325 ton ditahun 2014. Hal ini terjadi karena tingkat curah hujan yang rendah yang dapat menyebabkan penurunan hasil produksi, kesulitan mendapatkan sumber air yang mengakibatkan kekeringan sehingga banyak terjadinya gagal panen, selain itu penggunaan input yang berpengaruh terhadap produksi jagung (BPS, 2015).

Pada usahatani jagung, petani juga menggunakan pupuk dan obatobatan.Pupuk yang biasanya digunakan yaitu pupuk anorganik (Urea, dan NPK) serta pupuk organik cair (M-8 dan Super ACI). Hasil-hasil penelitian diketahui bahwa produksi jagung sebenarnya dapat mencapai tiga sampai dengan empat ton pipilan kering. Apa yang menyebabkan petani belum mencapai produksi tersebut perlu diteliti. Produksi yang tinggi akan tercapai apabila input-input produksi tersebut optimal penggunaannya. Perlu juga diteliti apakah dalam penggunaan input produksi sudah dilakukan secara optimal atau tidak.

\subsection{Rumusan Masalah}

Berdasarkan latar belakang yang diuraikan, maka dapat dirumuskan permasalahan sebagai berikut:

1. Bagaimana pengaruh input produksi terhadap hasil produksi usahatani jagung di Desa Waimangura. 
2. Bagaimana tingkat optimasi penggunaan input pada usahatani jagung di Desa Waimangura.

\subsection{Tujuan Penelitian}

Adapun tujuan dilakukannya penelitian ini adalah untuk mengetahui:

1. Untuk mengetahui pengaruh input produksi terhadap hasil produksi usahatani jagung di Desa Waimangura.

2. Untuk menganalisis tingkat optimasi penggunaan input pada usahatani jagung di Desa Waimangura.

\section{Metode Penelitian}

\subsection{Lokasi dan Waktu Penelitian}

Penelitian ini berlangsung mulai dari bulan Maret s.d April 2016 di Desa Waimangura, Kecamatan Wewewa Barat, Kabupaten Sumba Barat Daya. Data yang dipilih adalah data untuk satu kali musim yaitu pada musim tanam bulan Juli s.d September 2015. Pemilihan lokasi dilakukan dengan cara sengaja (purposive).

\subsection{Populasi dan Sampel}

Populasi dalam penelitian ini adalah petani yang melakukan usahatani jagung di Desa Waimangura yang berjumlah 255 KK. Metode penentuan sampel dilakukan secara teknik sampling probabilitas (random sampling) yaitu diambil sampel sebesar $30 \mathrm{KK}$ dari jumlah $255 \mathrm{KK}$ dengan penarikan sampel rambang sederhana adalah dengan undian. Penentuan sampel dilakukan untuk mempermudah dan mempercepat proses penelitian (Nasir,2005). Jumlah sampel dalam penelitian ini sebanyak $30 \mathrm{KK}$ agar bias diuji normalitas data tersebut. Sampel terbentuk mendekati distribusi normal ketika jumlah sampel mencapai minimum 30.

\subsection{Jenis dan Sumber Data}

Jenis data dalam penelitian ini adalah data kualitatif dan data kuantitatif. Sumber data terdiri atas data primer dan data sekunder. Data primer diperoleh dari observasi dan wawancara dengan petani sampel dengan menggunakan daftar pertanyaan yang dibuat terlebih dahulu. Pengamatan dilakukan terhadap karakteristik petani dan penggunaan sarana produksi usahatani. Karakteristik petani meliputi: data umur petani, pendidikan, pengalaman berusahatani, jumlah tanggungan sedangkan sarana produksi usahatani meliputi: luas lahan, penggunaan benih, pupuk organik maupun anorganik dan tenaga kerja, produktivitas tanaman serta harga masingmasing input produksi. Data sekunder diperoleh dari Dinas Pertanian Tanaman Pangan dan Hortikultura Sumba Barat Daya, Badan Pusat Statistik (BPS) Kabupaten Sumba Barat Daya, Kantor Desa Waimangura, dan internet. 


\subsection{Variabel dan Pengukuran}

Variabel penelitian menurut Sugiyono (2014) adalah segala sesuatu yang berbentuk apa saja yang ditetapkan oleh peneliti untuk dipelajari sehingga diperoleh informasi tentang hal tersebut, kemudian ditarik kesimpulan. Adapun variabel pada penelitian ini adalah luas lahan garapan $\left(\mathrm{X}_{1}\right)$, tenga kerja $\left(\mathrm{X}_{2}\right)$, benih $\left(\mathrm{X}_{3}\right)$, Pupuk Urea $\left(\mathrm{X}_{4}\right)$, Pupuk NPK $\left(\mathrm{X}_{5}\right)$, Pupuk M-8 $\left(\mathrm{X}_{6}\right)$, Pupuk Super ACI $\left(\mathrm{X}_{7}\right)$ dan Fungisida $\left(\mathrm{X}_{8}\right)$.

\subsection{AnalisisData}

Menurut Soekartawi (2003), untuk menganalisis input-input yang mempengaruhi produksi usahatani jagung digunakan fungsi produksi model CobbDouglas, dengan rumus sebagai berikut:

$$
Y_{i}=b_{0} X_{1 i}^{b 1} X_{2 i}^{b 2} X_{3 i} b^{3} X_{4 i}^{b 4} X_{5 i}^{b 5} X_{6 i} b^{6} X_{7 i} b^{7} X_{8 i}{ }^{b 8}
$$

Fungsi produksi diatas kemudian ditrasformasikan kedalam bentuk linier logaritma untuk mempermudah pengdugaan terhadap fungsi produksi, sehingga dapat dirumuskan sebagai berikut:

$$
\begin{aligned}
\operatorname{Ln} Y_{i} & =\ln b_{0}+b_{1} \ln X_{1 i}+b_{2} \ln X_{2 i}+b_{3} \ln X_{3 i}+b_{4} \ln X_{4 i}+b_{5} \ln X_{5 i} \\
& +b_{6} \ln X_{6 i}+b_{7} \ln X_{7 i}+b_{8} \ln X_{8 i}+u
\end{aligned}
$$

Menurut Agustira (2004), untuk menguji apakah variabel bebas yakni input produksi $\mathrm{X}_{\mathrm{i}}$ bersama-sama (serempak) berpengaruh terhadap variabel tidak bebas (Y) digunakan uji-F. Hipotesis yang digunakan dalam uji ini adalah:

$$
F_{\text {hitung }}=\frac{M S E}{M S R}=\frac{R^{2} / k-1}{\left(1-R^{2}\right) /(n-k)}
$$

Menurut Agustira (2004), untuk mengetahui sejauh mana variabel bebas ( $\left.\mathrm{X}_{\mathrm{i}}\right)$ dapat menjelaskan variabel tak bebas $(\mathrm{Y})$ digunakan nilai koefisien determinasi $\left(\mathrm{R}^{2}\right)$. Koefisien determinasi dapat dituliskan sebagai berikut:

$$
\mathrm{R}^{2}=\frac{\mathrm{SSR}}{\mathrm{SST}}=\frac{\mathrm{b}_{1} \sum \mathrm{Y}_{\mathrm{i}} \mathrm{X}_{1 \mathrm{i}}+\mathrm{b}_{2} \sum \mathrm{Y}_{\mathrm{i}} \mathrm{X}_{2 \mathrm{i}}+\ldots+\mathrm{b}_{\mathrm{k}} \sum \mathrm{Y}_{\mathrm{i}} \mathrm{X}_{\mathrm{ki}}}{\sum \mathrm{Yi}^{2}}
$$

Menurut Agustira (2004), untuk menguji apakah pengaruh bebas yakni input $\left(\mathrm{X}_{\mathrm{i}}\right)$ yang digunakan dari usahatani jagung secara parsial berpengaruh nyata terhadap hasil produksi $(Y)$ digunakan uji-t. Semua variabel bebas $\left(\mathrm{X}_{\mathrm{i}}\right)$ diuji satu persatu. Hipotesis yang diajukan adalah :

$$
\text { t-hitung }=b_{\mathrm{i}}=\frac{\mathrm{bi}}{\mathrm{S}_{\mathrm{bi}}} \text {. }
$$

Masalah kedua dianalisis menggunakan analisis efisiensi penggunaan input produksi yaitu efisiensi ekonomi. Tingkat optimasi faktor produksi usahatani jagung dihasilkan dari rasio nilai produk marginal (NPM) dengan harga masing-masing 
input produksi. Dengan melihat harga input produksi maka diperoleh tingkat optimasi masing-masing input produksi (Soekartawi, 2002) :

$$
\text { Tingkat optimasi }=\frac{\text { NPM xi }}{\text { Pxi }}
$$

Jika $\frac{\text { NPMxi }}{\text { Pxi }}=1$ maka input produksi tersebut sudah optimal.

Jika $\frac{\text { NPMxi }}{\text { Pxi }}<1$ maka penggunaan input produksi sudah tidak optimal dan harus dikurangi.

Jika $\frac{\text { NPMxi }}{\text { Pxi }}>1$ maka penggunaan input produksi belum optimal dan harus ditambahkan.

\section{Hasil dan Pembahasan}

\subsection{PengaruhPenggunaan Input terhadap Hasil Produksi Jagung}

Pengaruh penggunaan input produksi terhadap produksi jagung, perlu dibuat terlebih dahulu fungsi produksi pada usahatani jagung tersebut. Terlebih dahulu dibuat analisis penduga parameter fungsi produksi yang bertujuan untuk mengetahui input-input produksi yang mempengaruhi hasil produksi jagung. Model fungsi produksi yang digunakan adalah fungsi produksi Cobb-Douglas.

Variabel-variabel yang digunakan dalam model fungsi penduga adalah variabel yang tidak bebas yaitu produksi jagung (Y) dan variabel-variabel bebas yang diduga mempengaruhi produksi jagung $(\mathrm{X})$ yang terdiri dari luas lahan garapan $\left(\mathrm{X}_{1}\right)$, tenaga kerja $\left(\mathrm{X}_{2}\right)$, benih $\left(\mathrm{X}_{3}\right)$, pupuk Urea $\left(\mathrm{X}_{4}\right)$, pupuk NPK $\left(\mathrm{X}_{5}\right)$, pupuk Super ACI $\left(\mathrm{X}_{6}\right)$, pupuk M-8 $\left(\mathrm{X}_{7}\right)$, fungisida $\left(\mathrm{X}_{8}\right)$. Besarnya pengaruh input produksi yang tersedia terhadap produksi jagung dapat dilihat Tabel 1.

Tabel 1.

Hasil Analisis Input-input Yang Mempengaruhi Produksi Jagung di Daerah Penelitian

\begin{tabular}{lrrrr}
\hline \multicolumn{1}{c}{ Variabel } & $\begin{array}{r}\text { Koefisien } \\
\text { Regresi }\end{array}$ & $\mathrm{t}_{\text {hitung }}$ & $\mathrm{t}_{\text {tabel }}$ & Sig \\
\hline $\mathrm{Y}$ : Produksi (kg/ha) & 8,050 & 7,300 & 2,079 & 0,000 \\
$\mathrm{X}_{1}:$ Lahan garapan (ha) & $-0,286$ & $-1,830$ & 2,079 & 0,081 \\
$\mathrm{X}_{2}:$ Tenaga kerja (HKP/ha) & $-0,089$ & $-0,466$ & 2,079 & 0,646 \\
$\mathrm{X}_{3}$ : Benih (kg/ha) & $-0,355$ & $-1,887$ & 2,079 & 0,073 \\
$\mathrm{X}_{4}:$ Pupuk Urea (kg/ha) & 0,283 & 2,433 & 2,079 & 0,024 \\
X $_{5}$ : Pupuk NPK (kg/ha) & $-0,168$ & $-1,583$ & 2,079 & 0,128 \\
$\mathrm{X}_{6}:$ Pupuk M-8 (ml/ha) & 0,177 & 1,737 & 2,079 & 0,097 \\
$\mathrm{X}_{7}:$ Pupuk Super ACI (ml/ha) & 0,031 & 0,203 & 2,079 & 0,780 \\
$\mathrm{X}_{8}:$ Fungisida (gr/ha) & $-0,015$ & $-0,150$ & 2,079 & 0,882 \\
\hline
\end{tabular}


Berdasarkan Tabel 1, dibuatlah model fungsi produksi pada usahatani jagung yang diperoleh dari model Cobb-Douglas, yaitu :

$$
\mathrm{Y}=8,050 \mathrm{X}_{1}{ }^{-0,286} \mathrm{X}_{2}{ }^{-0,089} \mathrm{X}_{3}^{-0,355} \mathrm{X}_{4}^{0,283} \mathrm{X}_{5}^{-0,168} \mathrm{X}_{6}{ }^{0,177} \mathrm{X}_{7}^{0,031} \mathrm{X}_{8}^{-0,015}
$$

Ln $Y=8,034-0,286 \ln X_{1}-0,089 \ln X_{2}-0,355 \ln X_{3}+0,283 \ln X_{4}$

$-0,168 \ln \mathrm{X}_{5}+0,177 \ln \mathrm{X}_{6}+0,031 \ln \mathrm{X}_{7}-0,015 \ln \mathrm{X}_{8}$

\subsection{Pengaruh Penggunaan Input Produksi Secara Serempak terhadap Produksi Jagung (Uji F)}

Hasih uji pengaruh variabel secara serempak dengan menggunakan uji $\mathrm{F}$. Nilai signifikansi $\mathrm{F}$ adalah sebesar 0,00. Data hasil penelitian diperoleh hasil bahwa nilai $F_{\text {hitung }}$ yang diperoleh adalah sebesar 3,729 dan juga dilihat dari nilai $F_{\text {tabel }}$ sebesar 2,42. Nilai tersebut dapat kita lihat bahwa nilai $F_{\text {hitung }}(3,729)>F_{\text {tabel }}(2,42)$. Hal ini menunjukkan bahwa penggunaan input produksi yaitu luas lahan garapan, tenaga kerja, benih, pupuk Urea, pupuk NPK, pupuk organik cair M-8, pupuk organik cair Super ACI secara serempak di daerah penelitian berpengaruh terhadap hasil produksi jagung.

Hasil pendugaan model menunjukkan bahwa nilai koefisien determinasi $\left(\mathrm{R}^{2}\right)$ sebesar 0,587. Nilai koefisien determinasi $\left(\mathrm{R}^{2}\right)$ mempunyai arti bahwa sebesar 58,7\% dari variasi produksi usahatani jagung dapat dijelaskan oleh variasi input produksi seperti luas lahan, tenaga kerja, benih, pupuk Urea, pupuk NPK, pupuk M-8, pupuk Super ACI dan fungisida, sedangkan 41,3\% lagi dijelaskan oleh input-input lain diluar model. Input-input lain diluar model yang diduga berpengaruh terhadap produksi jagung misalnya adalah tingkat kesuburan tanah, jarak antara lahan dengan sumber air dan serangan hama penyakit.

\subsection{Pengaruh Penggunaan Input Produksi Secara Parsial terhadap ProduksiJagung (Uji t)}

Hubungan antara input produksi secara parsial terhadap hasil produksi jagung, yaitu apakah ada pengaruh penggunaan input produksi secara parsial terhadap produksi jagung, digunakan uji t. Berdasarkan Tabel 1 dapat dilihat bahwa hanya satu variabel yang memiliki nilai $t_{\text {hitung }}>t_{\text {tabel }}$ yaitu pupuk Urea. Variabel lainnya yaitu tenaga kerja, benih, pupuk Urea, pupuk NPK, pupuk M-8, pupuk Super ACI dan fungisida memiliki nilai $t_{\text {hitung }}<t_{\text {tabel }}$. Dapat disimpulkan bahwa input produksi yang berpengaruh nyata terhadap peningkatan produksi adalah pupuk Urea. Input lainnya yaitu tenaga kerja, benih, pupuk Urea, pupuk NPK, pupuk M-8, pupuk Super ACI dan fungisida, tidak berpengaruh nyata terhadap produksi jagung.

Secara parsial pengaruh variabel luas lahan garapan $\left(\mathrm{X}_{1}\right)$ tidak berpengaruh nyata terhadap hasil produksi jagung $(\mathrm{Y})$, dimana thitung $(-1,830)$ lebih kecil daripada $t_{\text {tabel }}(2,079)$. Variabel tenaga kerja $\left(\mathrm{X}_{2}\right)$ tidak berpengaruh nyata terhadap hasil produksi jagung $(\mathrm{Y})$, dimana $t_{\text {hitung }}(-0,466)$ lebih kecil daripada $t_{\text {tabel }}(2,079)$. Banyak 
atau sedikitnya penggunaan tenaga kerja bahkan keterampilan tenaga kerja tidak mempengaruhi hasil produksi.

Variabel benih $\left(\mathrm{X}_{3}\right)$ tidak berpengaruh nyata terhadap hasil produksi jagung (Y), dimana thitung $(-1,887)$ lebih kecil daripada $t_{\text {tabel }}(2,079)$. Variabel pupuk Urea $\left(\mathrm{X}_{4}\right)$ berpengaruh nyata terhadap hasil produksi jagung $(\mathrm{Y})$, dimana $\mathrm{t}_{\text {hitung }}(2,433)$ lebih besar daripada $t_{\text {tabel }}(2,079)$. Hal ini disebabkan pemberian pupuk Urea tidak sesuai dengan dosis yang di anjurkan, dan cara pemberian pupuk yang tepat pada waktunya, dimana rata-rata penggunaan pupuk Urea dilapangan sebesar $353,70 \mathrm{~kg} / \mathrm{ha}$ dan dosis yang dianjurkan sekitar $350 \mathrm{~kg} / \mathrm{ha}$. Pemberian pupuk tersebut telah melebihi dosis pupuk yang dianjurkan. Pupuk Urea juga banyak mengandung unsur Nitrogen yang dapat membantu pertumbuhan sampai dengan pematangan biji jagung, sehingga pupuk Urea mempengaruhi hasil produksi jagung di daerah penelitian.

Variabel pupuk NPK $\left(\mathrm{X}_{5}\right)$ tidak berpengaruh nyata terhadap hasil produksi jagung $(Y)$, dimana $t_{\text {hitung }}(-1,583)$ lebih kecil daripada $t_{\text {tabel }}(2,079)$. Variabel pupuk M-8 ( $\left.\mathrm{X}_{6}\right)$ tidak berpengaruh nyata terhadap hasil produksi jagung $(\mathrm{Y})$, dimana $\mathrm{t}_{\text {hitung }}$ $(1,737)$ lebih kecil daripada tabel $(2,079)$.

Variabel pupuk Super ACI $\left(\mathrm{X}_{7}\right)$ tidak berpengaruh nyata terhadap hasil produksi jagung (Y), dimana thitung $(0,283)$ lebih kecil daripada tabel $(2,079)$. Variabel fungisida $\left(\mathrm{X}_{8}\right)$ tidak berpengaruh nyata terhadap hasil produksi jagung $(\mathrm{Y})$, dimana $t_{\text {hitung }}(-0,150)$ lebih kecil daripada $t_{\text {tabel }}(2,079)$.

\subsection{Tingkat Optimasi Penggunaan Input Produksi pada Usahatani Jagung}

Tingkat optimasi penggunaan input produksi dilakukan melalui pendekatan nilai produk marjinal (NPM) yang dibandingkan terhadap harga satuan input produksi, dimana nilai produk marjinal (NPM) merupakan perkalian antara produk marjinal (PM) dengan harga produk per satuannya (disini merupakan harga rata-rata produk per satuan), dan harga satuan input produksi merupakan harga rata-rata input produksi per satuan.

Tingkat optimasi penggunaan input produksi dapat tercapai apabila rasio antara keduanya mempunyai nilai yang sama dengan satu $\left(\mathrm{NPM} / \mathrm{PX}_{\mathrm{i}}=1\right)$. Semakin dekat dengan nilai satu maka dikatakan bahwa penggunaan surah relatif lebih optimum dan apabila nilainya kurang dari satu berarti sudah tidak optimum.

Tingkat optimasi input produksi dihasilkan dari rasio nilai produk marjinal (NPM) dengan harga msing-masing input produksi (Pxi). Harga-harga input produksi yakni masing-masing adalah sebesar sewa lahan garapan Rp 862.500, tenaga kerja Rp 253.333, benih Rp 25.000, pupuk Urea Rp 90.000, pupuk NPK Rp 135.000, pupuk organik cair M-8 Rp 150.000, pupuk Super ACI Rp 150.000, dan fungisida Rp 10.000 dan harga rata-rata produksi yaitu $\mathrm{Rp} 2.500$, maka dapat diperoleh nilai tingkat optimasi masing-masing input produksi tersebut pada Tabel 2. 
Tabel 2.

Tingkat Optimasi Penggunaan Input Produksi Pada Usahatani Jagung

\begin{tabular}{lrrr}
\hline Variabel & $\begin{array}{c}\text { Penggunaan Input } \\
\text { Produksi }\end{array}$ & $\begin{array}{r}\text { Tingkat } \\
\text { Optimasi }\end{array}$ & Keterangan \\
\hline Luas Lahan $\left(\mathrm{X}_{1}\right)$ & $0,25 \mathrm{ha}$ & $-85.326,02$ & Tidak Optimal \\
Tenaga Kerja $\left(\mathrm{X}_{2}\right)$ & $212,97 \mathrm{HKP} / \mathrm{ha}$ & $-106,12$ & Tidak Optimal \\
Benih $\left(\mathrm{X}_{3}\right)$ & $25,02 \mathrm{~kg} / \mathrm{ha}$ & $-36.510,32$ & Tidak Optimal \\
Pupuk Urea $\left(\mathrm{X}_{4}\right)$ & $353,70 \mathrm{~kg} / \mathrm{ha}$ & 571,90 & Belum Optimal \\
Pupuk Npk $\left(\mathrm{X}_{5}\right)$ & $402,20 \mathrm{~kg} / \mathrm{ha}$ & $-199,04$ & Tidak Optimal \\
Pupuk M-8 $\left(\mathrm{X}_{6}\right)$ & $5920,14 \mathrm{ml} / \mathrm{ha}$ & 12,82 & Belum Optimal \\
Pupuk Super ACI $\left(\mathrm{X}_{7}\right)$ & $5500 \mathrm{ml} / \mathrm{ha}$ & 2.42 & Belum Optimal \\
Fungisida $\left(\mathrm{X}_{8}\right)$ & $109,12 \mathrm{gr} / \mathrm{ha}$ & $-884,30$ & Tidak Optimal \\
\hline
\end{tabular}

Berdasarkan Tabel 2 dapat dilihat bahwa pada penggunaan input produksi lahan, tenaga kerja, benih, pupuk NPK dan fungisida memiliki nilai optimasi $<1$. Hal ini menunjukkan bahwa input produksi tersebut melebihi optimal dan untuk menghasilkan produksi yang optimal, maka input tersebut harus dikurangkan. Input produksi lainnya yaitu pupuk Urea, pupuk M-8 dan pupuk Super ACI memiliki nilai optimasi > 1. Hal ini menunjukkan bahwa input-input produksi tersebut belum optimal dan untuk menghasilkan produksi yang optimal maka input tersebut harus ditambahkan penggunaannya.

Nilai optimasi input produksi luas lahan $\left(\mathrm{X}_{1}\right)$ diperoleh sebesar -85.326,02. Hal ini disebabkan karena penggunaan input produksi lainnya belum optimal dan harus ditambahkan penggunaannya, penggunaan input produksi hendaknya di sesuaikan dengan luas lahan yang ada, sehingga memungkinkan tercapainya produksi yang optimal

Nilai optimasi input produksi tenaga kerja $\left(\mathrm{X}_{2}\right)$ diperoleh angka sebesar 106,12. Hal ini berarti secara ekonomis bahwa pemakaian tenaga kerja sebesar 212,97 HKP/ha tidak optimal, untuk itu perlu dilakukan pengurangan input produksi tenaga kerja agar hasilnya dapat optimal.

Nilai optimasi penggunaan input produksi benih $\left(\mathrm{X}_{3}\right)$ diperoleh angka sebesar $-36.510,32$. Hal ini berarti secara ekonomis bahwa pemakaian benih sebesar $25,02 \mathrm{~kg} / \mathrm{ha}$ tidak optimal, untuk itu perlu dilakukan pengurangan agar hasilnya dapat optimal. Dimana rata-rata penggunaan benih dilapangan sebesar $25 \mathrm{~kg} / \mathrm{ha}$. Sedangkan dosis anjuran kebutuhan benih jagung per hektar berkisar antara $15 \mathrm{s.d} 20 \mathrm{~kg} / \mathrm{ha}$.

Nilai optimasi input produksi pupuk Urea $\left(\mathrm{X}_{4}\right)$ diperoleh angka sebesar 554,74. Hal ini menunjukkan secara ekonomis bahwa pemakaian pupuk Urea sebesar 353,70 belum optimal, untuk itu perlu dilakukan penambahan pemakaian pupuk Urea agar hasilnya dapat optimal. Dosis yang anjuran untuk kebutuhan pupuk Urea sebesar $450 \mathrm{~kg} / \mathrm{ha}$.

Nilai optimasi input produksi pupuk NPK $\left(\mathrm{X}_{5}\right)$ diperoleh angka sebesar 199,04. Hal ini menunjukkan secara ekonomis bahwa pemakaian pupuk NPK sebesar 402,20 tidak optimal, untuk itu perlu dilakukan pengurangan pemakaian 
pupuk NPK agar hasilnya dapat optimal. Dosis yang dianjurkan untuk pupuk NPK sebesar $400 \mathrm{~kg} / \mathrm{ha}$. Nilai optimasi input produksi pupuk M-8 ( $\left.\mathrm{X}_{6}\right)$ diperoleh angka sebesar 12,82 . Hal ini menunjukkan secara ekonomis bahwa pemakaian pupuk M-8 sebesar 5920,14 $\mathrm{ml} / \mathrm{ha}$ belum optimal, untuk itu perlu dilakukan penambahan pemakaian pupuk M-8 agar hasilnya dapat optimal.

Nilai optimasi input produksi pupuk Super ACI $\left(\mathrm{X}_{7}\right)$ diperoleh angka sebesar 2,42. Hal ini menunjukkan secara ekonomis bahwa pemakaian pupuk Super ACI sebesar $5500 \mathrm{ml} /$ ha belum optimal, untuk itu perlu dilakukan penambahan pemakaian pupuk Super ACI agar hasilnya dapat optimal.

Nilai optimasi input produksi fungisida $\left(\mathrm{X}_{8}\right)$ diperoleh angka sebesar -884,30. Hal ini menunjukkan secara ekonomis bahwa pemakaian pupuk fungisida sebesar 109,12 gr/ha tidak optimal, untuk itu perlu dilakukan pengurangan pemakaian fungisida agar hasilnya dapat optimal. Pemakaian fungisida pada satu $\mathrm{kg}$ benih yaitu sebesar. Pengunaan fungisida Saromyl-35 SD per kilogram benih di daerah penelitian sebesar $5 \mathrm{~kg}$. Dosis yang dianjurkan untuk pemakaian Saromyl-35 SD yaitu $1,25 \mathrm{s.d} 2,5 \mathrm{gr} / \mathrm{kg}$ benih.

\section{Simpulan dan Saran \\ 4.1 Simpulan}

Berdasarkan hasil penelitian dan pembahasan sebelumna, maka dapat disimpulkan bahwa penggunaan input produksi luas lahan, tenga kerja, benih, pupuk Urea, pupuk NPK, pupuk M-8, pupuk Super ACI dan fungisida secara serempak berpengaruh nyata terhadap hasi produksi jagung di Desa Waimangura. Berbagai input yang digunakan dalam usahatani jagung di Desa Waimangura ternyata input pupuk Urea, pupuk M-8 dan pupuk Super ACI penggunaannya belum optimal. Input yaitu luas lahan, tenaga kerja benih, pupuk NPK dan fungisida penngunaannya tidak optimal.

\subsection{Saran}

Peningkatan produksi jagung disarankan agar petani lebih memperhatikan efisien penggunaan input produksi yaitu lahan garapan, tenaga kerja, benih, pupuk Urea, pupuk NPK, pupuk M-8 pupuk Super ACI, dan fungisida untuk mencapai kondisi yang lebih optimal. Kepada Pemerintah Daerah Sumba Barat Daya dapat melakukan penyuluhan kepada petani tentang penggunaan input produksi seperti luas lahan, tenga kerja, benih, pupuk Urea, pupuk NPK, pupuk M-8, pupuk Super ACI dan fungisida agar dapat memberi nilai produksi lebih tinggi.

\section{Ucapan Terima Kasih}

Terima kasih kepada seluruh pihak yang telah memberikan pengarahan, bmbingan dan juga dukungan dalam penyelesaian penelitian dan penulisan ejurnalini. Semoga penelitian ini dapat bermanfaat sebagaimana mestinya 


\section{Daftar Pustaka}

Agustira, M.A. 2004. Analisis Optimasi Penggunaan Input Produksi pada Usahatani Padi Sawah di Kabupaten Deli Serdang. Skripsi. Fakultas Pertanian Universitas Sumatera Utara, Medan. [Online] http://repository.usu.ac.id/xmlui/handle/123456789/38325? show=full

Badan Pusat Statistik Kabupaten Sumba Barat Daya. 2015. Statistik Pertanian Sumba Barat Daya 2015. BPS Kabupaten Sumba Barat Daya.

Khalik, R. S. 2010. Diservikasi Konsumsi Pangan di indonesia:Antara Harapan dan Kenyataan. Pusat analisis sosial ekonomi dan kebijakan pertanian. Bogor.

Nasir. M. 2005. Metodologi Penelitian, Ghalia Indonesia, Jakarta.

Rukmana, R. 2008. Usaha Tani Jagung. Kansius. Yogyakarta.

Siregar, G. S. 2009. Analisis Respon Penawaran Komoditas Jagung dalam Rangka Mencapai Swasembada Jagung di Indonesia. Bogor: Institut pertanian Bogor. [Online] https://core.ac.uk/download/pdf/32347496.pdf

Soekartawi. 2002. Analisis Usahatani. UI Press. Jakarta.

Soekartawi. 2003. Teori Ekonomi Produksi (Dengan Pokok Bahasan Analisis Fungsi Cobb-Douglas). Raja Grafindo. Jakarta.

Sugiyono. 2014. Metode Penelitian Pendidikan Pendekatan Kuantitatif, Kualitatif Dan R\&D. Bandung: Alfabeta.

Suwardi dan Roy E. 2009. Efisiensi Penggunaan Pupuk N pada Jagung Komposit Menggunakan Bagan warna Daun. Jurnal Balai Penelitian Tanaman Serealia, Jakarta. [Online] http://fp.unila.ac.id/wpcontent/uploads/sites/16/2013/03/JAT-11-50-54-Januari-2013.pdf 